\title{
COMPLEMENTARY AND ALTERNATIVE MEDICINE IN SERBIA: A LITERATURE REVIEW
}

\author{
Marina Luketina-Šunjka1, Nemanja Rančić2, Slobodan Subotić3, Mihajlo Jakovljević4,5
}

\begin{abstract}
The aim of this review paper is to present the state of complementary and alternative medicine in the Republic of Serbia and compare it with other developing and developed countries around the world.

In most countries of the world, the legalization and integration of the Complementary and Alternative Medicine (CAM) into the health system went very slowly until the 1970s, when there was an important global change in socioeconomic conditions. WHO estimates that \$ 83 billion was spent on traditional medicine in the world market in 2008. Significant variations in financial allocations to CAM across the globe have been observed, however, their direct comparison has been hampered by differences in the definitions and categorization of CAM used, as well as by the use of different currencies in different time periods. The development of CAM in the Balkans, during the 1990s, was hampered by war and transition, and the resolution of CAM was delayed. For the first time, the law regulates the implementation of the CAM in Serbia in 2005 by Article 235 of the Health Care Act.

In the Republic of Serbia, evidence of the extent of use of CAM methods is very modest, although worldwide research shows an accelerated upward trend in the use of CAM. This paper is our contribution to the further development and better recognition of CAM methods by both the Ministry of Health of the Republic of Serbia and the professional public. Acta Medica Medianae 2020;59(3):98-104.
\end{abstract}

Key words: complementary and alternative medicine, CAM, treatment methods, rehabilitation methods

\footnotetext{
${ }^{1}$ European Center for Peace and Development, University for Peace established by the United Nations, Belgrade, Serbia

${ }^{2}$ Faculty of Medicine of the Military Medical Academy, Centre for Clinical Pharmacology, University of Defense, Belgrade, Serbia

${ }^{3}$ College for Health Studies "Milutin Milanković", Belgrade,

Serbia

${ }^{4}$ University of Kragujevac, Faculty of Medical Sciences,

Department of Global Health Economics and Policy,

Kragujevac, Serbia

${ }^{5}$ Institute of Comparative Economic Studies, Hosei University,

Tokyo, Japan
}

Contact: Nemanja Rančić

MMA, Crnotravska 17, 11000 Belgrade, Serbia

E-mail: nece84@hotmail.com medicine (CAM) into their health systems (1). The legalization and integration of CAM into health systems in most countries of the world went very slowly until the 1970s, when there was an important global change in socio-economic conditions (1).

WHO estimates that $\$ 83$ billion was spent on traditional medicine in the world market in 2008. Thereafter, "in May 2009, the WHO Assembly adopted resolution 62.13, inviting all Member States and national governments to cooperate and share knowledge while working to strengthen the link between conventional and traditional practitioners" (2).

\section{The aim}

The aim of this revision paper is to present the state of CAM in Serbia and compare it with other developing and developed countries around the world.

\section{CAM in Serbia: Legislation and Division of CAM Methods}

The development of CAM in the Balkans, during the 1990s, was hampered by war and transition, and the resolution of CAM was delayed (3). At the beginning of the transition in 1989, in our country, all the weaknesses of the current health system
States include traditional therapists, i.e practitioners of the methods of complementary and alternative 
(lack of money, unfavorable contracts between the Health Insurance Fund and health institutions and others) emerged, which made it necessary to move towards changes in the health policy and the health system (4).

For the first time, the law regulates the implementation of the CAM in Serbia in 2005 by Article 235 of the Health Care Act (5). In the following way: "Traditional medicine, within the meaning of this Law, includes those proven professionally unchallenged traditional, complementary and alternative methods and procedures of diagnosis, treatment and rehabilitation that have a beneficial effect or which may have a beneficial effect on a men health or his health status and which are not covered by health services in accordance with applicable medical doctrine" (5). Later on, the methods of diagnosis, treatment and rehabilitation of CAM were defined by the Ordinance on the closer conditions, manner and procedure of performing the methods and procedures of traditional medicine from 2007 (6).

The methods of diagnosis and treatment of traditional medicine were: Ayurveda; acupuncture and related techniques; traditional Chinese medicine; homeopathy; phytotherapy; quantum medicine and related techniques; chiropractic and applied kinesiology; macrobiotics and traditional home medi- cine (6).The methods of rehabilitation of traditional medicine were classified as: apitherapy; aroma therapy; Chi Gong exercises; spiritual energy medicine; energy therapy, Reiki; detection of harmful radiation; yoga exercises; family schedule and Tai Chi Chi exercise (6). In 2018, a new Ordinance was adopted on the closer conditions, manner and procedure for performing the methods and procedures of traditional medicine (7).

In 2019, the Law on Health Care was amended so that the term traditional medicine was replaced by the term complementary medicine, which within the meaning of this law includes "those traditional and complementary methods and procedures of prevention, diagnostic evaluation, treatment, health care and rehabilitation that have a beneficial effect on human health or medical condition and which, in accordance with applicable medical doctrine, are not covered by conventional medicine methods and procedures" (8).

In January 2020, in accordance with the amendments to the Law on Health Care, the Rulebook on Closer Conditions and Methods of Performing Complementary Medicine Methods and Procedures entered into force, authorizing a total of 12 complementary medicine methods, which are shown in Table 1 (9).

Table 1. Complementary medicine methods approved in Serbia

\begin{tabular}{|l||}
\hline \multicolumn{1}{|c||}{ I. Methods of prevention, diagnostic evaluation, treatment and rehabilitation: } \\
1. Acupuncture \\
2. Acupuncture microsystem stimulation methods \\
3. Quantum Medicine \\
4. Homeopathy \\
5. Traditional Chinese Medicine \\
6. Ayurveda - Traditional Indian Medicine \\
7. Chiropractic \\
8. Osteopathy \\
\hline 9. Aromatherapy II. Methods of preserving and improving health: \\
10. Reiki \\
11. Anthroposophy medicine \\
12. Qi gong (dao yin), yoga, that qi chu practice for medical purposes \\
\hline
\end{tabular}

This Rulebook defines that a healthcare professional may perform complementary medicine methods if he or she has completed the relevant integrated academic studies of the health profession, that is, an appropriate high or high school of health profession, has the approval of the competent chamber of health workers for independent work (license) and has the decision of the minister responsible for health for performing a specific com- plementary medicine method (license) (9).The permit is issued to a healthcare professional who, in addition to the statutory requirements, must have a certificate of completion of continuing medical education for a specific area of complementary medicine, i.e. adequate higher education for the method of traditional Chinese medicine, Ayurveda-traditional Indian medicine, homeopathy and chiropractic (9). So far, traditional methods and procedures in Serbia 
are not funded by the State Health Insurance Fund (1).

\section{Republic of Serbia}

A number of CAM studies have been conducted in Serbia, and the most important will be presented in this paper. In Vojvodina, being Serbian province, a study was conducted on the population of patients using pharmacy services in this province. The study found that $10.4 \%$ of respondents (out of $1,137)$ used some herbal preparations for the prevention and/or therapy of gastrointestinal and liver disorders, most commonly for constipation (44\%) and dyspepsia (23\%) (10). Buckthorns-based preparations (16.1\%), including Alder buckthorn (8.5\%) and dietary fiber preparations (6\%) were used by subjects for constipation (10), while preparations with artichoke $(11 \%)$ and silymarin (9.3\%) were most commonly used for liver disorders (10). The decision to choose an herbal preparation was made on the recommendation of a pharmacist (35.6\%) or on the patient's own initiative $(32.2 \%)$, and less frequently on the advice of a physician or other person (10).

A multicenter study conducted as a crosssectional study of patients in general practitioners' clinics in five Health Centers in Serbia (in Zrenjanin, Pančevo, Zaječar, Zemun and the outpatient department of the Institute for Public Health of the employees of the Ministry of Internal Affairs of Serbia in Belgrade) showed that out of 1,157 respondents, $83.66 \%$ of those used traditional medicine methods (11). Phytotherapy (48.8\%) and traditional folk medicine $(34.7 \%)$ were the most commonly used methods of traditional medicine for diagnostics and treatment, and apitherapy (34.7\%) were the most used methods (11). Respondents under 65 years of age used acupuncture, Chinese traditional medicine, homeopathy, chiropractic and macrobiotics more often, while respondents over 65 used traditional folk medicine more often (11). Information on traditional medicine methods was most commonly obtained from acquaintances and friends (54.9\%) and through the media (39.3\%) (11). There was no significant difference in the way information was obtained in relation to gender, and statistically significantly more frequent information via the Internet was obtained by persons younger than 65 years of age (11). Respondents in the city are more likely to receive information about traditional medicine methods online from doctors and pharmacists, and in the countryside from acquaintances and friends (11). The availability of traditional medicine to the urban population was more important, while the price to the rural population was the most important (11).

At the Institute of Oncology of Vojvodina, in the population of patients diagnosed with gastroenterological malignancy, a study was conducted, which showed that 48 (24.9\%) patients did not use any of the alternative medicine methods, while at least one alternative therapy used 145 (75.1\%) patients (12). About $64 \%$ used herbal preparations, most commonly beet juice (about 57\%) (12). Mind and body medicine based therapies were used by $16.6 \%$ of patients, while spiritual therapy was used by $18.1 \%$ of patients and special diets were used by $19.2 \%$ of patients (12). Patients were most often informed of alternative therapy by other patients, relatives and neighbors (70.5\% of patients) (12).

A study was conducted over total of 300 subjects who underwent chemotherapy at the Clinic for Medical Oncology at the Institute of Oncology and Radiology of Serbia in Belgrade in three time periods: in 1993, 2000 and 2008 (13). The percentage of patients using any of the CAM methods was over $50 \%$ in all three observed time periods (13). In 1993 and 2000, about $10 \%$ of patients reported that their physicians suggested the use of CAM, while in 2008 this percentage increased to $30 \%$ (13).

More educated patients used CAM more often compared to patients who had only primary education (13). The percentage of CAM users among college-educated patients increased from $20 \%$ in 1993 to $33 \%$ in 2008 (13).

Patients believed that CAM would enhance their immunity (this result was almost identical in all three observed time periods, i.e. approximately $65 \%$ of patients) (13). A third of CAM users believed that CAM would cure malignant disease, while most patients expected better effects of standard treatment with CAM (13).

A study conducted in eight Serbian cities among physicians, dentists and pharmacists employed by public and private healthcare institutions, as well as medical, dental and pharmacy students from two state universities found that dental students were better informed about CAM than medical students, pharmacists better than university students professors, while primary care healthcare professionals were more familiar with CAM than pharmacists in public pharmacies (14). Among the students and among employed health professionals, the most commonly used types of CAM were vitamins (71.01\% vs. 54.48\%) (14).

In a 2019 cross-sectional study conducted in Serbia among consumers of CAM, two-thirds $(65.3 \%)$ of users take OTC preparations on their own initiative, without a prescription and without a doctor's recommendation (15). It was noted in a study that users of CAM services and consumers of OTC preparations were less frequently hospitalized without the use of sick leave, ambulance, or home treatment in the previous 12 months (15).

\section{countries}

\section{Research in the field of CAM in other}

In the Republic of Serbia, evidence on the extent of the use of CAM methods is very modest, although worldwide research shows an accelerated upward trend in the use of CAM (15). Higher education and high incomes have been significant predictors in most of the studies conducted so far in the world, probably because in most countries CAM is paid out of pocket, so patients with high incomes and usually from professions requiring higher education are able to self-finance the use of CAM (1619). However, some studies have shown a significant impact of lower education levels $(20,21)$.

The situation is similar in most countries in the region. Recently, the methods of CAM have been 
developing and becoming more popular in Croatia $(22,23)$. According to the results of a study on the use of CAM in a sample of 228 respondents at the Health Center in Čakovec, $82 \%$ of respondents used at least some form of CAM (22). CAM was more commonly used by women, as well as high school graduates, employees and retirees (24). The most commonly used medicinal herbs $(87 \%)$, bioenergy (29\%) and diet therapy (28\%) (24). Vitamin and mineral supplements were used by $77 \%$ of the respondents (24). CAM was most commonly used to treat diseases of the respiratory tract, urinary tract, musculoskeletal system, as well as to improve the general condition (24). Of the respondents who used CAM, 55\% believed it would help (24). Another study conducted in Croatia found that $46 \%$ of respondents had used CAM at least once in their lifetime, that the most commonly used methods were herbalism (38\%), homeopathy (15.6\%) and acupuncture $(13.1 \%)$, and that the most common beneficiaries were persons between 46 and 55 years of age and of higher education (25). A study conducted on 267 patients with malignancies also showed a high prevalence-60.3\%, with naturopathy/folk medicine being the most prevalent, with independent predictors of CAM use being high incomes, divorce, women, and younger life expectancy (26). The use of herbal medicine was specially observed in all parts of Croatia, and traditionally, a large number of herbs were used in the form of teas, tinctures, hydrolysates, fats and oil extracts $(27,28)$.

A study conducted in Hungary found that $63.9 \%$ of surgical patients were interested in using CAM, and $26.8 \%$ were using naturopathy (29). According to this study, CAM was more used by women, patients with university degrees, and patients with endocrine diseases (29). A study conducted among anesthetists and surgeons in this country found that they also frequently used CAM methods in their clinical practice such as reflexology, traditional Chinese medicine, herbal medicine and manual therapy (30). A study conducted among breast cancer patients in Hungary found that $52.6 \%$ of them used CAM before diagnosis, and $84.4 \%$ during treatment, with CAM being more commonly used by more educated women and those living in cities, while during treatment, use was more common in higher-income patients (31).

A comparative study conducted among doctors in Romania and Hungary found that significantly more Hungarian doctors (33.6\%) would be more likely to refer patients to CAM practitioners compared to Romanian doctors $(12.8 \%)$, while the percentage of physicians who once referred a patient to CAM practitioners were approximately similar (57.9\% vs. 54.7\%) (32). Compared to the countries mentioned above, the situation in Slovenia and Bulgaria is somewhat different. In these countries it has been shown that the prevalence of CAM use in the last 12 months is much lower and is below $10 \%$ (33). On the other hand, a survey in the Czech Republic showed that about $76 \%$ of the general population had used one or more CAM methods in the previous 30 days in 2011, while in 2014 this percentage was significantly higher and amounted to $87 \%(34,35)$.

In both years, vitamins and minerals, herbal remedies, massage and relaxation techniques were most commonly used $(33,34)$. A study in Poland showed that the prevalence of using CAM methods in epilepsy patients was $26.8 \%$, with the most commonly used CAM methods being herbal and dietary supplements (32.3\%) and energy treatment $(31.5 \%)(36)$. The use of CAM was more common in younger patients with longer duration of epilepsy who did not experience remission and who had lower levels of education (35).

Significant variations in financial allocations to CAM across the globe have been observed, but their direct comparison is hampered by differences in the definitions and categorization of CAM used, as well as by the use of different currencies in different time periods (16). In the Republic of Serbia a total of RSD329,966,634.66 was spent on herbal and traditional medicines in 2010, i.e. EUR3,104,233.14 ( $0.43 \%$ of total drug turnover) (36), and in 2017 RSD1,012,173,801.44, i.e. EUR8,543,714.03 (0.87\% of total drug turnover) (37), while in 2010, a total of RSD30,541,699.02 was spent on homeopathic medicines. EUR287,073.69 (0.04\% of total drug turnover) (36), and in 2017, RDS95,585,188.77, i.e. EUR806,830.33 (0.08\% of total drug turnover) (37).

A systematic review of studies addressing the prevalence of CAM use in the UK showed that the average cost of using CAM per patient per month was GBP15.99 (range 8.80-28) (38). The estimated total financial allocation in the United Kingdom on an annual basis was GBP1.6 billion in 1999 (39).

In Australia, the total estimated amount spent on CAM products paid out of pocket was AUD621 million in 1993 (40), AUD1.671 million in 2000 (41), AUD1.308 million in 2004 (42) and AUD1.860 million in 2005 (44), with CAM practitioners estimated to have earmarked AUD309 million from citizens' pocket in 1993 (40), AUD616 million in 2000 (41), AUD494 million in 2004 (42) and 1.730 million of Australian dollars in 2005 (43). In Canada, a total of CAD3.8 billion was estimated to have been spent on CAM in 1997 (44) and CAD7.8 billion in CAM (45). In the US, citizens estimated that a total of USD10.3 billion was earmarked in their pocket in 1990 (46), USD34.4 billion in 1997 (47), USD33.9 billion in 2007 (48) and USD30.2 billion in 2012 (49).

\section{Conclusion}

This paper is our contribution to the further development and better recognition of CAM methods by both the Ministry of Health of the Republic of Serbia and the professional public. There is a need to conduct research that will allow us to understand both the scope of use of alternative treatment methods and the main characteristics of users in terms of their demographic, socio-economic characteristics and health status, as well as a comparative analysis of the use of health care services and alternative medicine methods. Therefore, there is a need to work together with the Ministry of Health and the 
Ministry of Education to form academic studies within the Faculty of Medical Sciences in the form of specialist studies in the field of CAM, in order to provide a high level of training and liaise with universities in the world where this has already been achieved, in order to network and share knowledge. It would also be very good to introduce into the existing practice the methods already approved by the Ministry of Health in the regular practice.

References

1. Jović S, Stambolović V. Tradicionalna, komplementarna i alternativna medicina u Srbiji-legalizacija i integracija u zdravstveni sistem. MD-Medical Data. 2013;5(4):373-8.

2. Robinson MM, Zhang X. Traditional Medicines: Global Situation, Issues and Challenges. The World Medicines Situation. $3^{\text {rd }}$ edition. Geneva, Switzerland: World Health Organization, 2011. Available from: URL: http://digicollection.org/hss/documents/s18063en/s18 063en.pdf

3. Cupara S, Djordjevic V, Jakovljevic M. Current legal status and research on complementary and alternative medicine in Serbia. J Altern Med Res 2013;5(3): 1958.

4. Jakovljevic M. Resource allocation strategies in Southeastern European health policy. Eur J Health Econ 2013;14(2):153-9. [CrossRef] [PubMed]

5. Zakon o zdravstvenoj zaštiti. Službeni glasnik RS br. 107/2005. [Internet]. [update 2019 June].

Available from URL: https://www.pravno-informacioni sistem.rs/SIGlasnikPortal/eli/rep/sgrs/skupstina/zakon 2005/107/5/req

6. Pravilnik o bližim uslovima, načinu i postupku obavljanja metoda i postupaka tradicionalne medicine. Službeni glasnik RS br. 119/2007. [Internet]. [update 2019 June].

Available from URL: http://demo.paragraf.rs/demo/ combined/Old/t/t2007 12/t12 0104.htm.

7. Pravilnik o bližim uslovima, načinu i postupku obavljanja metoda i postupaka tradicionalne medicine. Službeni glasnik RS br. 16/2018. [Internet]. [update 2020 June].

Available from URL: http://www.quanttes.org.rs/wpcontent/uploads/2018/08/NOVI-Pravilnik-2018.pdf

8. Zakon o zdravstvenoj zaštiti. Službeni glasnik RS br. 25/2019-40. [Internet]. [update 2020 June].

Available from URL: https://www.pravno-informacioni -sistem.rs/SIGlasnikPortal/eli/rep/sgrs/skupstina/ zakon/2019/25/2

9. Pravilnik o bližim uslovima i načinu obavljanja metoda i postupaka komplementarne medicine. "Službeni glasnik RS", br. 1/2020. [Internet]. [update 2020 January].

Available from URL: http://www.pravno-informacioniistem.rs/SIGlasnikPortal/eli/rep/sgrs/ministarstva/prav inik/2020/1/2.
10. Hitl M, Gavarić N, Kladar N, Brkić S, Samojlik I, Dragović G, et al. Herbal preparations use in prevention and treatment of gastrointestinal and hepatic disorders-Data from Vojvodina, Serbia. Complement Ther Med. 2019;43:265-70. [CrossRef] [PubMed]

11. Petrov-Kiurski M, Prvanov D, Stanojlović O, KondićIvanović N, Popović K. How often do patients in primary care use the methods of traditional medicine. Opšta Med. 2014;20(3-4):77-87. [CrossRef]

12. Nikolić $I$, Smiljenić $D$, Kukić $B$, Bogdanović $B$, Petrović $\mathrm{T}$, Ivković-Kapicl T, et al. Application of alternative medicine in gastrointestinal cancer patients. Vojnosanit Pregl. 2012;69(11):947-50. [CrossRef] [PubMed]

13. Berat S, Radulovic S. Trends in use of and attitudes held towards alternative and complementary medicine among patients treated in a Department of Medical Oncology in Serbia. A several-years-apart time survey study. J BUON. 2014;19(2):535-9. [PubMed]

14. Jakovljevic MB, Djordjevic V, Markovic V, Milovanovic O, Rancic NK, Cupara SM. Cross-sectional survey on complementary and alternative medicine awareness among health care professionals and students using CHBQ questionnaire in a Balkan country. Chin J Integr Med. 2013;19(9):650-5. [CrossRef]

15. Luketina-Šunjka M, Rancic N, Mihailovic N, Jakovljevic $M$. The Impact of the Socio-Demographic Characteristics of Complementary and Alternative Medicine Users in Serbia on OTC Drug Consumption. Front Public Health 2019;7:303. [CrossRef] [PubMed]

16. Pejcic AV, Jakovljevic MB. Economic impact of traditional medicine practice worldwide. Tradit Med Res. 2017;2(2):60-74.

17. Kemppainen LM, Kemppainen TT, Reippainen JA, Salmenniemi ST, Vuolanto PH. Use of complementary and alternative medicine in Europe: Health-related and sociodemographic determinants. Scand J Public Health. 2018;46(4):448-55. [CrossRef] [PubMed]

18. Keene MR, Heslop IM, Sabesan SS, Glass BD. Complementary and alternative medicine use in cancer: A systematic review. Complement Ther Clin Pract. 2019;35:33-47. [CrossRef] [PubMed]

19. Yang L, Sibbritt D, Adams J. A critical review of complementary and alternative medicine use among people with arthritis: a focus upon prevalence, cost, user profiles, motivation, decision-making, perceived 
benefits and communication. Rheumatol Int 2017; 37(3):337-51. [CrossRef] [PubMed]

20. Peltzer K, Pengpid S. Prevalence and Determinants of Traditional, Complementary and Alternative Medicine Provider Use among Adults from 32 Countries. Chin J Integr Med 2018;24(8): 584-90. [CrossRef] [PubMed]

21. Yang L, Sibbritt D, Adams J. A critical review of complementary and alternative medicine use among people with arthritis: a focus upon prevalence, cost, user profiles, motivation, decision-making, perceived benefits and communication. Rheumatol Int 2017;37 (3):337-51. [CrossRef] [PubMed]

22. Radovčić Z, Nola IA. Integracija komplementarne i alternativne medicine $s$ primarnom zdravstvenom zaštitom u Republici Hrvatskoj - mišljenja liječnika primarne zdravstvene zaštite. Acta Med Croatica 2015;69(5):451-7.

23. Pavić Ž, Milanović G. Komplementarna i alternativna medicina u Hrvatskoj: testiranje triju hipoteza. SocijaIna ekologija 2014;23(2):95-119.

24. Vitale K, Munđar R, Sović S, Bergman-Marković B, Janev Holcer N. [Use of complementary and alternative medicine among family medicine patients-example of the town of Čakovec]. Acta Med Croatica. 2014;68(4-5):345-51. [PubMed]

25. Cizmesija T, Bergman-Marković B. Use of complementary and alternative medicine among the patients in primary health care. Acta Med Croatica 2008; 62 (1):15-22. [PubMed]

26. Kust D, Šamija I, Marić-Brozić J, Svetec B, Miletić M, Mamić G, et al. Use of Alternative and Complementary Medicine in Patients with Malignant Diseases in HighVolume Cancer Center and Future Aspects. Acta Clin Croat 2016;55(4):585-92. [CrossRef] [PubMed]

27. Brenko A, Dugac Ž, Randić M. Narodna medicina. Zagreb: Etnografski muzej Zagreb; 2001.

28. Bukovčan T. Advocacy and Activism in Complementary and Alternative Medicine Research - a Croatian Example. Anthropology in Action 2007;15:35-42. [CrossRef]

29. Soós SÁ, Jeszenői N, Darvas K, Harsányi L. Complementary and alternative medicine use in surgical patients. Orv Hetil 2016;157(37):1483-8. [CrossRef] [PubMed]

30. Soós SÁ, Jeszenői N, Darvas K, Harsányi L. Complementary and alternative medicine: attitudes, knowledge and use among surgeons and anaesthesiologists in Hungary. BMC Complement Altern Med 2016;16(1):443. [CrossRef] [PubMed]

31. Sárváry A, Sárváry A. Use of complementary and alternative medicine among breast cancer patients in Hungary: A descriptive study. Complement Ther Clin Pract 2019;35:195-200. [CrossRef] [PubMed]

32. Jupaneant O, Hegyi G, Tudor A, Dragan S. Comparative Study on Complementary and Alternative Medicine (CAM) Use by Physicians in Romania and Hungary. Jurnalul Pediatrului 2014;17(67-68):71-7.

33. Pokladnikova J, Selke-Krulichova I. Prevalence of Complementary and Alternative Medicine Use in the General Population in the Czech Republic. Forsch Komplementmed 2016;23(1):22-8.

[CrossRef] [PubMed]

34. Pokladnikova J, Selke-Krulichova I. The Use of Complementary and Alternative Medicine by the General Population in the Czech Republic: A Follow-Up Study. Complement Med Res 2018;25(3):159-66. [CrossRef] [PubMed]

35. Bosak M, Słowik A. Use of complementary and alternative medicine among adults with epilepsy in a university epilepsy clinic in Poland. Epilepsy Behav 2019;98(Pt A):40-4. [CrossRef] [PubMed]
36. Agencija za lekove i medicinska sredstva Srbije. Promet i potrošnja gotovih lekova za humanu upotrebu u Republici Srbiji u 2010. godini. Beograd, 2011. [Internet]. [update 2020 January].

Available from URL: https://www.alims.gov.rs/ciril/files/2013/02/Promet 2 010.pdf

37. Agencija za lekove i medicinska sredstva Srbije. Promet i potrošnja gotovih lekova za humanu upotrebu u Republici Srbiji u 2017. godini. Beograd, 2018. [Internet]. [update 2020 January].

Available from URL: https://www.alims.gov.rs/ciril/files/2019/07/092 13 01575201950021 pdf.pdf

38. Posadzki P, Watson LK, Alotaibi A, Ernst E. Prevalence of use of complementary and alternative medicine (CAM) by patients/consumers in the UK: systematic review of surveys. Clin Med (Lond) 2013;13(2):12631. [CrossRef] [PubMed]

39. Ernst $E$, White A. The BBC survey of complementary medicine use in the UK. Complement Ther Med 2000; 8(1): 32-6. [CrossRef] [PubMed]

40. MacLennan A, Wilson D, Taylor A. Prevalence and cost of alternative medicine in Australia. The Lancet 1996; 347(9001):569-73. [CrossRef] [PubMed]

41. MacLennan A, Wilson D, Wilson DH, Taylor AW. The Escalating Cost and Prevalence of Alternative Medicine. Prev Med 2002;35(2):166-73.

[CrossRef] [PubMed]

42. MacLennan AH, Myers SP, Taylor AW. The continuing use of complementary and alternative medicine in South Australia: costs and beliefs in 2004. Med J Aust 2006;184(1):27-31. [CrossRef] [PubMed]

43. Xue CC, Zhang AL, Lin V, Da Costa C, Story DF. Complementary and Alternative Medicine Use in Australia: A National Population-Based Survey. J Altern Complement Med 2007;13(6):643-50.

[CrossRef] [PubMed]

44. Ramsay S, Walker M, Alexander J. Alternative Medicine in Canada: Use and Public Attitudes. Vancouver: The Fraser Institute, 1999. [Internet]. [update 2020 January]. Available from: URL:

https://www.fraserinstitute.org/sites/default/files/Alter nativeMedicineinCanada1999.pdf.

45. Esmail N. Complementary and Alternative Medicine in Canada: Trends in Use and Public Attitudes, 19972006. Vancouver: The Fraser Institute, 2007. [Internet]. [update 2020 January].

Available from URL:

https://www.fraserinstitute.org/sites/default/files/Com plementaryAlternativeMedicine.pdf

46. Eisenberg DM, Kessler RC, Foster C, Norlock FE, Calkins DR, Delbanco TL. Unconventional medicine in the United States. Prevalence, costs, and patterns of use. N Engl J Med 1993;328(4):246-52. [CrossRef] [PubMed]

47. Eisenberg DM, Davis RB, Ettner SL, Appel S, Wilkey S, Van Rompay $M$, et al. Trends in alternative medicine use in the United States, 1990-1997: results of a follow-up national survey. JAMA 1998;280(18):156975. [CrossRef] [PubMed]

48. Nahin RL, Barnes PM, Stussman BJ, Bloom B. Costs of complementary and alternative medicine (CAM) and frequency of visits to CAM practitioners: United States, 2007. Natl Health Stat Rep 2009;(18):1-14. [PubMed]

49. Nahin RL, Barnes PM, Stussman BJ. Expenditures on Complementary Health Approaches: United States, 2012. Natl Health Stat Rep 2016;(95):1-11. [PubMed] 


\title{
KOMPLEMENTARNA I ALTERNATIVNA MEDICINA U SRBIJI: PREGLED LITERATURE
}

\author{
Marina Luketina-Šunjka ${ }^{1}$, Nemanja Rančić ${ }^{2}$, Slobodan Subotić3 , Mihajlo Jakovljevićt,5 \\ ${ }^{1}$ Univezitet pod pokroviteljstvom Ujedinjenih nacija, Evropski centar za mir i razvoj, Beograd, Srbija \\ ¿Univerzitet odbrane, Medicinski fakultet Vojnomedicinske akademije, Centar za kliničku farmakologiju, Beograd, \\ Srbija \\ "Visoka medicinska škola strukovnih studija "Milutin Milanković", Beograd, Srbija \\ ${ }^{4}$ Univerzitet u Kragujevcu, Fakultet medicinskih nauka, Katedra za globalno zdravlje, zdravstvenu ekonomiju i \\ politiku, Kragujevac, Srbija \\ ${ }^{5}$ Hosei Univerzitet, Institut za uporedne ekonomske studije, Tokio, Japan
}

Kontakt: Nemanja Rančić

VMA, Crnotravska 17, 11000 Beograd, Srbija

E-mail: nece84@hotmail.com

Cilj ovog revijskog rada je analiza stanja komplementarne i alternativne medicine u Srbiji i poređenje sa stanjima u drugim razvijenim zemljama i zemljama u razvoju širom sveta.

U većini zemalja sveta, legalizacija i integracija komplementarne i alternativne medicine (KAM) u zdravstveni sistem išla je veoma sporo sve do 1970-ih godina, kada je došlo do značajne globalne promene društveno-ekonomskih uslova. Svetska zdravstvena organizacija procenjuje da je na tradicionalnu medicinu, na svetskom nivou, potrošeno 83 milijarde dolara tokom 2008. godine. Primećene su značajne razlike u finansijskim izdvajanjima za KAM širom sveta, međutim njihovo direktno upoređivanje je otežano usled razlika u definicijama i kategorizaciji korištenih KAM, kao i upotrebom različitih valuta u različitim vremenskim periodima. Razvoj KAM na Balkanu, tokom devedesetih godina dvadesetog veka, ometali su rat i proces tranzicije, a donošenje odluka u vezi sa KAM je odloženo. Zakonom je, po prvi put, regulisana primena KAM u Srbiji 2005. godine članom 235. Zakona o zdravstvenoj zaštiti.

U Srbiji su dokazi o obimu primene metoda KAM vrlo skromni, mada svetska istraživanja pokazuju ubrzani trend porasta primene KAM. Ovaj rad je naš doprinos daljem razvoju i boljem prepoznavanju metoda KAM, kako od strane Ministarstva zdravlja, tako i od strane stručne javnosti.

Acta Medica Medianae 2020;59(3):98-104.

Ključne reči: komplementarna $i$ alternativna medicina, KAM, metode lečenja, metode rehabilitacije 